International Journal of

Environmental Research and

Public Health

ISSN 1660-4601

www.mdpi.com/journal/ijerph

Review

\title{
Impact of the 2008 Economic and Financial Crisis on Child Health: A Systematic Review
}

Luis Rajmil $^{1,2,3 * *}$, María-José Fernandez de Sanmamed ${ }^{4}$, Imti Choonara ${ }^{5}$, Tomas Faresjö ${ }^{6}$, Anders Hjern ${ }^{7}$, Anita L. Kozyrskyj ${ }^{8}$, Patricia J. Lucas ${ }^{9}$, Hein Raat ${ }^{10}$, Louise Séguin ${ }^{11}$, Nick Spencer ${ }^{12}$ and David Taylor-Robinson ${ }^{13}$ on Behalf of the International Network for Research in Inequalities in Child Health (INRICH)

1 Agència de Qualitat i Avaluació Sanitàries (AQuAS), Barcelona 08005, Spain

2 Fundació Institut Mar d'Investigacions Mèdiques (IMIM), Barcelona 08003, Spain

3 CIBER de Epidemiología y Salud Pública, Madrid 28029, Spain

4 General Practitioner, Homer 22, Barcelona 08023, Spain; E-Mail: 14848mfs@comb.cat

5 Academic Division of Child Health, The Medical School, University of Nottingham, Derbyshire Children's Hospital, Uttoxeter Road, Derby DE22 3DT, UK; E-Mail: Imti.Choonara@ nottingham.ac.uk

6 Division of Community Medicine, Department of Medical and Health Sciences, Linköping University, Linköping S-581 85, Sweden; E-Mail: tomas.faresjo@liu.se

7 Centre for Health Equity Studies (CHESS), Karolinska Institutet, Stockholm University, Stockholm 106 91, Sweden; E-Mail: anders.hjern@chess.su.se

8 Department of Pediatrics; University of Alberta, University Ave., Edmonton, AB 11402, Canada; E-Mail: kozyrsky@ualberta.ca

9 School for Policy Studies, University of Bristol, Bristol BS8 1TZ, UK;

E-Mail: Patricia.Lucas@bristol.ac.uk

10 Department of Public Health, The Erasmus University Medical Center, Rotterdam, Dr. Molewaterplein 50, P.O. Box 2040, 3000 CA Rotterdam, The Netherlands;

E-Mail: h.raat@erasmusmc.nl

11 Department of Social and Preventive Medicine, Université de Montréal, C.P. 6128, Succursale Centre-ville, Montréal (Québec), QC H3C 3J7, Canada; E-Mail: louise.seguin@ umontreal.ca

12 Division of Mental Health and Wellbeing, Warwick Medical School, University of Warwick, Coventry CV4 7AL, UK; E-Mail: n.j.spencer@warwick.ac.uk

13 Department of Public Health and Policy, University of Liverpool, Liverpool L69 3GB, UK; E-Mail: David.Taylor-Robinson@liverpool.ac.uk

* Author to whom correspondence should be addressed; E-Mail: 1rajmil@ gencat.cat; Tel.: +34-935-513-922; Fax: +34-935-517-510. 
Received: 18 April 2014; in revised form: 9 June 2014 / Accepted: 10 June 2014 /

Published: 23 June 2014

\begin{abstract}
The aim of this study was to provide an overview of studies in which the impact of the 2008 economic crisis on child health was reported. Structured searches of PubMed, and ISI Web of Knowledge, were conducted. Quantitative and qualitative studies reporting health outcomes on children, published since 2007 and related to the 2008 economic crisis were included. Two reviewers independently assessed studies for inclusion. Data were synthesised as a narrative review. Five hundred and six titles and abstracts were reviewed, from which 22 studies were included. The risk of bias for quantitative studies was mixed while qualitative studies showed low risk of bias. An excess of 28,000-50,000 infant deaths in 2009 was estimated in sub-Saharan African countries, and increased infant mortality in Greece was reported. Increased price of foods was related to worsening nutrition habits in disadvantaged families worldwide. An increase in violence against children was reported in the U.S., and inequalities in health-related quality of life appeared in some countries. Most studies suggest that the economic crisis has harmed children's health, and disproportionately affected the most vulnerable groups. There is an urgent need for further studies to monitor the child health effects of the global recession and to inform appropriate public policy responses.
\end{abstract}

Keywords: adolescent; child health; economic and financial crisis; inequalities

\title{
1. Introduction
}

The current global economic and financial crisis, which began at the end of 2007 in the U.S., poses a major threat to health and affects mainly Europe and several other countries [1]. Economic downturns are known to affect health and living conditions of the populations. The impact of crisis in each country depends on the type of recession (duration and intensity, the speed of changes, and the types of changes that occur), the situation prior to the recession, the measures adopted by the states and governments in response to the crisis, and the role played by communities and family structure in the lives of individuals [2].

There is a large body of work on recession and health, most of it in adults. There are both positive (i.e., road traffic accidents go down) and negative effects (i.e., suicides generally go up) documented [3]. There are fewer data for children and youth. Children are a vulnerable population group and strong evidence exists on the link between socioeconomic living conditions and child health [4]. The literature on previous recessions in different countries and periods suggest that exposure to poverty in early life and during childhood for prolonged periods may have a strong and irreversible impact on physical, cognitive and social health of the childhood population [5]. Exposure to poverty in early life has been shown to be associated with a higher risk of chronic health conditions of elderly people such as cardio-vascular diseases [6,7] and Alzheimer's disease [8-10]. 
The role of social determinants of health is essential in the pathways of influence of economic crisis on child health [11]. Reduced opportunities for employment increases income poverty, restrict food budget, decrease housing security/quality (e.g., via evictions and moves) and harm parental mental health [12]. Increased food costs restrict food budgets for all. Decreased spending on public services could lead to reduced health care provision, decreased social protection spending, and cuts in effective health promotion initiatives, including maternal health and early child development programmes. Child labour may increase with attendant impacts on health and education [5,13].

The level of social inequalities and social gradients during childhood in itself can also have an important role on health outcomes both in the short and the longer term [14]. Mechanisms of social protection (such as social welfare payments) implemented by countries are likely to be effective in mitigating the effects of economic shocks on child health [15], but austerity measures adopted in many countries during the current economic crisis have reduced social protection mechanisms, thus potentially contributing to increased health inequalities $[1,3]$. Some studies have reported on the impact of the current economic crisis on families and children in Greece [16], Spain [17,18], the UK [19], and the U.S. [20]. In Greece youth unemployment rose from 18.6\% to 40.1\% from 2008 to 2011. In Spain, child poverty increased by $53 \%$ between 2007 and 2010. There are an estimated 3.5 million children living in poverty in the UK and this figure is expected to increase by 600,000 by 2015/2016 [21]. However, few data exist on the impact of the current economic crisis on child health so it is important to summarise what we know across studies reporting to date.

The objective of the present systematic review is to provide an overview of studies in which the impact of the 2008 economic and financial crisis on child health was analysed, in order to assess the evidence base to inform public health policy and identify research gaps.

\section{Methods}

A structured search was carried out in September 2013 in the databases PubMed, and ISI Web of Knowledge using terms for financial recession and terms for childhood. Languages included Dutch, English, French, Italian, Spanish, and Swedish. A Google search using the terms "crises OR downturn OR recession OR Economic Recession OR austerity AND child OR adolescent OR youth OR infant OR paediatrics" was also conducted, and the first 200 entries from Google were screened. All references lists of included studies were included, and an expert group, the International Network for Research in Inequalities in Child Health, were asked to identify any additional studies known to them.

\subsection{Inclusion and Exclusion Criteria}

Both quantitative and qualitative studies were included, where they considered the impact of the current economic crisis on child health (children and young people <18 year). Longitudinal studies needed to compare a period before and after December 2007 (starting point of the current crisis), cross sectional studies needed to have collected data during the period 2008-2013. General population studies were included if results on the child population were identified separately. Outcomes included any mortalities, morbidities or wider child health impacts. Intermediate outcomes such as food consumption patterns were also considered given their potential for short and long term impacts on child nutrition and physical health. Studies on the impact of previous economic crises were excluded in 
the analysis as well as studies only analysing adult health. Given the scarcity of data, grey literature and none peer reviewed manuscripts were included if other selection criteria were fulfilled.

\subsection{Study Selection}

Abstracts obtained by the initial search strategy were assessed for possible inclusion by two researchers (L. Rajmil, M.J. Fernández de Sanmamed) and full text papers of all studies potentially includable (or unclear). Differences of opinion on inclusion were resolved by consensus.

\subsection{Study Appraisal}

The risk of bias of included studies was assessed by two authors (L. Rajmil, M.J. Fernández de Sanmamed) using the Strengthening the Reporting of Observational Studies in Epidemiology (STROBE) initiative for quantitative studies [22]. Qualitative studies were assessed using EPICURE (Engagement, Processing, Interpretation, Critique Usefulness, Relevance and Ethics) [23]. For quantitative studies, each criterion, from the total of 22 , was awarded one point, 0.5 or 0 (Zero) points if adjudged to be fully, partially or not at all presented; studies scoring 16 or over were adjudged to have a low risk of bias; those scoring $7-15$ as moderate risk, and those scoring $<7$ as high risk of bias. For qualitative studies, four out of the seven items (P, I, U, R) were considered essential to assess studies as average or low risk of bias (the latter if also met at least one of the other items). The lack of one or more of these four essential items was considered as high risk of bias. Given the scarcity of data on the study subject it was decided to avoid using quality assessment criteria as an exclusion criteria but to further carry out a sensitivity analysis and to assess the strengths of evidence of the included studies.

\subsection{Data Extraction and Analysis}

Data were extracted using a standardised data extraction form. Data extracted included: setting (according to the country: international, national or regional study); type of study (before-after comparative study, cross-sectional study, etc.); objectives of the study; years covered by the study; the specific target population; age range; exposure(s) measure(s) investigated (individual or ecologic variables such as unemployment rate, Gross Domestic Product, sociodemographic variables); outcome measures (classified as mortality, health-related quality of life, mental health, etc.); and the results in terms of impact on child health. The data was classified and organised according to the main outcome measure of the study. Quantitative and qualitative studies were analysed separately and the results presented together according to the outcome measure. Given the heterogeneity of studies in terms of study design (mainly observational and descriptive), participants, and outcomes, we undertook a narrative synthesis of the results. These are reported in the following categories: infant and child mortality; food habits and nutrition; health behaviours, non-accidental injuries, mental health and health-related quality of life; and chronic conditions. 


\section{Results}

Figure 1 shows the results of the literature search. In all 506 documents were screened. From the 311 titles and abstracts reviewed 200 were initially excluded, most of them addressing previous crises and/or the impact on adult health; 109 documents were full text screened, and finally 24 documents corresponding to 22 studies were included (one study published three documents).

Figure 1. Flow chart of the study selection process.

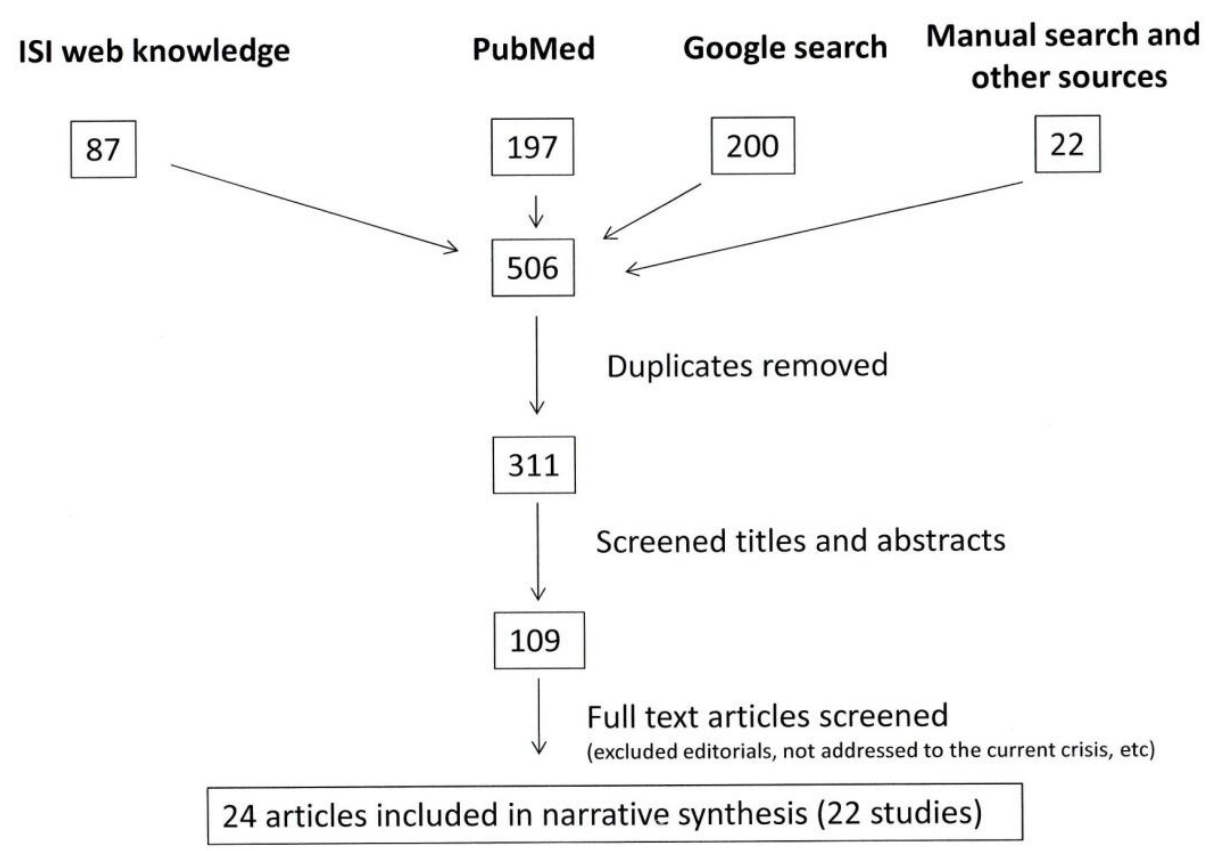

\subsection{Study Characteristics}

Nineteen quantitative studies, two qualitative studies and one study with mixed quantitative and qualitative methods were included in the review. Thirteen quantitative studies analysed trends over time [24-36] and four of them showed a low risk of bias (Table 1) [25,31,32,36]. Six were cross-sectional studies [37-42] three of which showed a low risk of bias [38,39,41]. Two qualitative studies were included: one was carried out in developing countries [43-45], and one in the UK [46]. All except one qualitative sub-study [45] showed low risk of bias on the EPICURE assessment. The study with mixed methods [47] showed moderate risk of bias on its quantitative approach and low risk of bias on qualitative approach. 
Table 1. Characteristics of included studies.

\begin{tabular}{|c|c|c|c|c|c|c|c|}
\hline First Author & Countries & Type of Study & Year(s) & Population/Sample & Source of Data (n) & Outcome Measure (s) & $\begin{array}{l}\text { Risk of Bias } \\
\text { (Score) } *\end{array}$ \\
\hline \multicolumn{8}{|c|}{ Quantitative studies: trends over time } \\
\hline Ariizumi [24] & Canada & Mortality trends & 1977-2009 & All ages & Canadian Vital Statistics Data & Under 15 year mortality & 15 \\
\hline Friedman [25] & $\begin{array}{l}30 \text { Sub- } \\
\text { Saharan } \\
\text { African } \\
\text { countries }\end{array}$ & $\begin{array}{l}\text { Infant mortality } \\
\text { trend } \\
\text { modelisation }\end{array}$ & $2007-2009$ & $\begin{array}{l}<1 \text { year /Women 15-49 } \\
\text { years old }\end{array}$ & $\begin{array}{l}\text { Demographic Health Survey. } \\
\text { Data from } 260,000 \text { women and } \\
640,000 \text { live births }\end{array}$ & Infant mortality & 16 \\
\hline Simó [26] & $\begin{array}{l}\text { Greece, } \\
\text { Spain, } \\
\text { OECD ** } \\
\text { countries }\end{array}$ & $\begin{array}{l}\text { Infant, neonatal, } \\
\text { and perinatal } \\
\text { mortality trends }\end{array}$ & $1990-2010$ & $<1$ year & OECD ** data on mortality & $\begin{array}{l}\text { Infant, perinatal } \\
\text { and neonatal }\end{array}$ & 7.5 \\
\hline Vlachadis [27] & Greece & $\begin{array}{l}\text { Descriptive } \\
\text { time-trends }\end{array}$ & 1966-2010 & $\begin{array}{l}\text { All recorded live births and } \\
\text { fetal deaths }\end{array}$ & Helenic Statistical Authority & $\begin{array}{l}\text { Stillbirths per } 1000 \\
\text { women }\end{array}$ & 7.5 \\
\hline Gordon [28] & UK & $\begin{array}{l}\text { Cross-sectional } \\
\text { survey and } \\
\text { time trends } \\
\text { description }\end{array}$ & $\begin{array}{l}\text { Surveys } \\
\text { conducted } \\
\text { in 1982, } \\
1990,1999, \\
2012 \\
\end{array}$ & Children (ages not specified) & $\begin{array}{l}\text { Necessities of Life survey } \\
(\mathrm{N}=2462 \text { adults }) . \text { Living standard } \\
\text { survey ( } \mathrm{N}=5193 \text { households })\end{array}$ & $\begin{array}{l}\text { Basic needs } \\
\text { ( } 30 \text { items for children). } \\
\text { Multiple deprivation }\end{array}$ & 14.5 \\
\hline $\begin{array}{l}\text { Department for } \\
\text { Environment } \\
\text { Food and } \\
\text { Rural Affairs } \\
\text { (DEFRA) [29] }\end{array}$ & UK & $\begin{array}{l}\text { Trends based on } \\
\text { cross-sectional } \\
\text { repeated surveys }\end{array}$ & $2007-2011$ & $\begin{array}{l}\text { General population of } \\
\text { households with children } \\
\text { (ages not specified) }\end{array}$ & $\begin{array}{l}\text { Family Food Survey } \\
(\mathrm{N}=\text { approximately } 6000 \text { households } \\
\text { a year) }\end{array}$ & $\begin{array}{l}\text { Household spending on } \\
\text { food, and comparisons } \\
\text { with healthy diet }\end{array}$ & 12.5 \\
\hline Sulaiman [30] & Bangladesh & $\begin{array}{l}\text { Longitudinal } \\
\text { rural panel and } \\
2 \text { urban cross } \\
\text { sectional samples }\end{array}$ & 2006,2008 & $\begin{array}{l}\text { Children } 0-59 \text { months in } \\
2006 / 24-82 \text { months in } 2008\end{array}$ & $\begin{array}{l}\text { Nutritional project } 2006 \text {. In 2008: } \\
\text { subsample of } 1163 \text { rural households, } \\
\text { and } 435 \text { urban households }\end{array}$ & $\begin{array}{l}\text { Weight-for-height } Z \text { score } \\
\text { in children. Changes of } \\
\text { food consumption. }\end{array}$ & 12.5 \\
\hline
\end{tabular}


Table 1. Cont

\begin{tabular}{|c|c|c|c|c|c|c|c|}
\hline First Author & Countries & Type of Study & Year(s) & Population/Sample & Source of Data (n) & Outcome Measure (s) & $\begin{array}{l}\text { Risk of Bias } \\
\text { (Score) } *\end{array}$ \\
\hline Berger [31] & U.S. & $\begin{array}{l}\text { Comparison } \\
\text { before-during } \\
\text { the recession }\end{array}$ & $\begin{array}{l}2004- \\
\text { 2007/December } \\
\text { 2007-June 2009 }\end{array}$ & $\begin{array}{l}<5 \text { year Population of } \\
74 \text { counties in } 3 \text { areas. }\end{array}$ & $\begin{array}{l}\text { Incidence of } \mathrm{AHT}^{\ddagger} \text { in children under } \\
5 \text { year. Hospital discharge records } \\
(\mathrm{N}=422)\end{array}$ & $\begin{array}{l}\text { Changes in rates of } \\
\text { hospitalisation due to AHT }\end{array}$ & 20 \\
\hline Huang [32] & OH, U.S. & $\begin{array}{l}\text { Incidence rates } \\
\text { over time }\end{array}$ & $\begin{array}{l}\text { 2001-November } \\
\text { 2007/December } \\
\text { 2007-June } 2010\end{array}$ & $<2$ year & $\begin{array}{l}\text { Incidence of injuries and } \mathrm{AHT}^{\ddagger} \\
\text { Hospital discharge records }(\mathrm{N}=639) \text {. } \\
\text { Study from } 1 \text { hospital }\end{array}$ & $\begin{array}{l}\text { Changes in rates of } \\
\text { hospitalisation due to AHT }\end{array}$ & 18 \\
\hline $\begin{array}{l}\text { Brooks-Gunn } \\
\text { [33] }\end{array}$ & U.S. & $\begin{array}{l}\text { Prospective } \\
\text { cohort study }\end{array}$ & $\begin{array}{l}\text { May } 2007- \\
\text { February } 2010\end{array}$ & 9 year-old children & $\begin{array}{l}\text { Wave of Fragile Families Child } \\
\text { Well-being Study. } 5000 \text { families of } \\
20 \text { large cities from } 15 \text { States }\end{array}$ & $\begin{array}{l}\text { Frequency of maternal } \\
\text { spanking }\end{array}$ & 16 \\
\hline Cui [34] & U.S. & $\begin{array}{l}\text { Trends based } \\
\text { on repeated } \\
\text { cross-sectional } \\
\text { surveys } \\
\end{array}$ & $\begin{array}{l}\text { 2001-2010 U.S. } \\
\text { general } \\
\text { population } \\
\text { sample }\end{array}$ & 12-17 year & $\begin{array}{l}\text { National Health and Nutrition } \\
\text { Examination Survey (NHAMES) }\end{array}$ & $\begin{array}{l}\text { Self-rated health, } \\
\text { unhealthy days and activity } \\
\text { limitation days }\end{array}$ & 16 \\
\hline Millet [35] & U.S. & $\begin{array}{l}\text { Before-after } \\
\text { approach }\end{array}$ & 2001-2010 & Child under 18 year & $\begin{array}{l}\text { Public available administrative data } \\
\text { for } 7 \text { States }\end{array}$ & $\begin{array}{l}\text { Child abuse and } \\
\text { maltreatment reported to } \\
\text { social services }\end{array}$ & 10 \\
\hline Rajmil [36] & $\begin{array}{l}\text { Catalonia, } \\
\text { Spain }\end{array}$ & $\begin{array}{l}\text { Before-after } \\
\text { approach }\end{array}$ & $\begin{array}{l}2006- \\
2010 / 2012\end{array}$ & $\begin{array}{l}0-14 \text { year General } \\
\text { population }\end{array}$ & $\begin{array}{l}\text { Catalan Health interview Survey } \\
2006(\mathrm{~N}=2200) \text { and Continuous } \\
\text { health survey 2010-2012 ( } \mathrm{N}=1967)\end{array}$ & $\begin{array}{l}\text { Health behaviors, obesity, } \\
\text { mental health and } \\
\text { perceived heatlh and } \\
\text { quality of life }\end{array}$ & 17 \\
\hline
\end{tabular}


Table 1. Cont

\begin{tabular}{|c|c|c|c|c|c|c|c|}
\hline First Author & Countries & Type of Study & Year(s) & Population/Sample & Source of Data (n) & Outcome Measure (s) & $\begin{array}{l}\text { Risk of Bias } \\
\text { (Score) } *\end{array}$ \\
\hline \multicolumn{8}{|c|}{ Quantitative studies: cross sectional } \\
\hline $\begin{array}{l}\text { Catalonian } \\
\text { ombudsman [37] }\end{array}$ & $\begin{array}{l}\text { Catalonia, } \\
\text { Spain }\end{array}$ & Cross-sectional & 2013 & $\begin{array}{l}<16 \text { year General population } \\
\text { from Catalonia }\end{array}$ & $\begin{array}{l}\text { European Union Statistics on Income } \\
\text { and Living Conditions (EU-SILC) } \\
\text { and other sources }\end{array}$ & $\begin{array}{l}\text { Reported food } \\
\text { consumption. } \\
\text { Multiple deprivation }\end{array}$ & 5.5 \\
\hline Samuels [47] & Nigeria & Cross sectional & 2009 & Households with children & National household surveys & $\begin{array}{l}\text { Reported food } \\
\text { consumption }\end{array}$ & 10 \\
\hline Bruening [38] & MN, U.S. & Cross-sectional & $\begin{array}{l}2009-2010 \\
\text { Population- } \\
\text { based study }\end{array}$ & Adolescents & $\begin{array}{l}\text { Household Food Insecurity } \\
\text { questionnaire (Families and Eating } \\
\text { Activity Among Teens study) } \\
\text { (N=2095 parents) }\end{array}$ & $\begin{array}{l}\text { Family food security } \\
\text { status }\end{array}$ & 17 \\
\hline Jackson [39] & U.S. & $\begin{array}{l}\text { Comparison of } \\
\text { two cross- } \\
\text { sectional studies }\end{array}$ & 2008-2010 & $\begin{array}{l}<18 \text { year children with asthma } \\
\text { and their parents }\end{array}$ & $\begin{array}{l}\text { Behavioural Risk Factor Surveillance } \\
\text { System phone interview ( } 2008 \\
\mathrm{~N}=4133 / 2010 \mathrm{~N}=3492 \text { parents) }\end{array}$ & $\begin{array}{l}\text { Parental smoking } \\
\text { behavior }\end{array}$ & 16 \\
\hline Pearlman [40] & U.S. & Cross-sectional & 2007-2009 & $\begin{array}{l}2-17 \text { year children with } \\
\text { asthma }\end{array}$ & $\begin{array}{l}\text { U.S. national Child Asthma Call-Back } \\
\text { survey. Parents of children with } \\
\text { asthma }(\mathrm{N}=5138)\end{array}$ & Level of asthma control & 13.5 \\
\hline Tarantino [41] & U.S. & $\begin{array}{l}\text { Cross-sectional } \\
\text { survey }\end{array}$ & 2009-2010 & $\begin{array}{l}<26 \text { year Patients with } \\
\text { haemophilia and their } \\
\text { caregivers (where }<26 \text { year, } \\
\text { average age = } 11.2 \text { year) } \\
\text { Hematologists }\end{array}$ & $\begin{array}{l}\text { Survey designed } a d \text { hoc } \\
(\mathrm{N}=70 \text { caregivers of }<26 \text { year with } \\
\text { Hemophilia } \mathrm{A} \text {, and adult patients, } \\
\mathrm{N}=64)\end{array}$ & $\begin{array}{l}\text { Changes in treatment } \\
\text { decision-making after } \\
\text { downturn. Attitude towards } \\
\text { healthcare reform }\end{array}$ & 16 \\
\hline $\begin{array}{l}\text { Anagnostopoulos } \\
\text { [42] }\end{array}$ & Greece & $\begin{array}{l}\text { Descriptive } \\
\text { cross sectional } \\
\text { study }\end{array}$ & $2000-2011$ & $\begin{array}{l}\text { Child and adolescent } \\
\text { population attending } \\
\text { psychiatric services }\end{array}$ & $\begin{array}{l}\text { National Action Plan Psychargos on } \\
\text { mental healthcare services }\end{array}$ & $\begin{array}{l}\text { Changes on the distribution } \\
\text { of mental health diagnoses } \\
\text { among users }\end{array}$ & 6 \\
\hline
\end{tabular}


Table 1. Cont.

\begin{tabular}{|c|c|c|c|c|c|c|}
\hline First Author & Countries & Type of Study & Year(s) & Sample & Study Aims & Risk of Bias * \\
\hline \multicolumn{7}{|c|}{ Qualitative studies } \\
\hline $\begin{array}{l}\text { Heltberg [43] } \\
\text { Hossain [44] } \\
\text { Hossain [45] }\end{array}$ & $\begin{array}{l}\text { Developing } \\
\text { countries } \\
17 \text { in } 2008, \\
6 \text { in } 2009, \\
4 \text { in } 2011 \\
\end{array}$ & $\begin{array}{l}\text { Focus groups } \\
\text { and interviews }\end{array}$ & 2008-2011 & $\begin{array}{l}\text { Children (ages not specified. } \\
\text { Respondents selected that } \\
\text { represent groups exposed to } \\
\text { economic shock) }\end{array}$ & $\begin{array}{l}\text { To study perceptions and behaviors of people as live crisis } \\
\text { impact and major coping responses used by poor and vulnerable } \\
\text { people and households }\end{array}$ & $\begin{array}{l}\text { EPICURe, } \\
\text { EPICURe } \\
\text { and epicURe } \\
\text { respectively }\end{array}$ \\
\hline Samuels [47] & Nigeria & $\begin{array}{l}\text { Key informants } \\
\text { interviews, } \\
\text { focus groups } \\
\text { and in-depth } \\
\text { interviews } \\
\end{array}$ & 2009 & $\begin{array}{l}\text { Children (ages not specified) } \\
6 \text { Nigerian zones that reflect } \\
\text { demographic and } \\
\text { socioeconomic heterogeneity }\end{array}$ & $\begin{array}{l}\text { To analyse the impact of } 3 \mathrm{~F}^{\dagger} \text { crisis on vulnerable social groups } \\
\text { (women and children) and coping strategies undertaken by } \\
\text { households during the period of food, fuel and financial crisis }\end{array}$ & EPICURe \\
\hline Halls [46] & UK & $\begin{array}{l}\text { Semi-structured } \\
\text { interviews and } \\
\text { participant } \\
\text { observation } \\
\text { (Ethnographic } \\
\text { approach) }\end{array}$ & $\begin{array}{l}\text { December } \\
2011 \text { and } \\
\text { January } \\
2012\end{array}$ & $\begin{array}{l}\text { Theoretically driven sample of } \\
11 \text { families with children } \\
\text { (ages not specified) with } \\
\text { different social status over } \\
5 \text { visits }\end{array}$ & $\begin{array}{l}\text { To analyse the lived experience of families against a backdrop } \\
\text { of austerity. Impact of austerity on family life and family } \\
\text { food choices }\end{array}$ & ePIcURE \\
\hline
\end{tabular}

Notes: * The risk of bias was assessed using the STROBE criteria for quantitative studies (range 0-22 points); for qualitative studies the uppercase and lowercase indicate compliance or non-compliance (or absence) of a given item from the 7 items of the (see methods section for more information); ** OECD: Organisation for Economic Cooperation and Development; ${ }^{\ddagger}$ AHT Abussive head trauma; ${ }^{\dagger} 3 \mathrm{~F}$ crisis: food, fuel and financial shock. 


\subsubsection{Infant and Child Mortality}

Four studies reported mortality outcomes. One modelling study estimated an excess of 28,000-50,000 infant deaths in the year 2009 in sub-Saharan African countries based on interviews with a random sample of 260,000 mothers (Table 2) [25]. National vital statistics in Greece reported an increase of $32 \%$ in stillbirths between 2008 and 2010, and also increases in infant, perinatal and neonatal mortality [27], while no influence was found on infant mortality in Spain [26], or under 15 year mortality in Canada [24].

Table 2. Impact of the 2008 economic crisis on infant and child mortality.

\begin{tabular}{lll}
\hline Countries & Results & Study \\
\hline 30 Sub Saharan & $\begin{array}{l}\text { Excess of 28,000-50,000 infant deaths in 2009, most of them girls } \\
\text { (compared to period 1977-2008). There are 3 million infant deaths a year } \\
\text { Africa Countries }\end{array}$ & Friedman J. [25] \\
\hline \multirow{2}{*}{ in these countries (infant mortality rate was 90/1000 in 2005). } & Simó J. [26] \\
\hline \multirow{2}{*}{ Greece } & $\begin{array}{l}\text { Perinatal, neonatal and infant mortality all increased by 20\% to 30\% from } \\
\text { 2008 to 2010 in Greece. No changes were found for Spain. }\end{array}$ & Vlachadis N. [27] \\
\hline \multirow{2}{*}{ Canada } & $\begin{array}{l}\text { Stillbirth rate increased from 3.31/1000 in 2008 to 4.28/1000 in 2009 and } \\
\text { 4.36/1000 in 2010 (a 32\% increase over 2 years). }\end{array}$ & Ariizumi H. [24] \\
\hline
\end{tabular}

\subsubsection{Food Habits and Nutrition}

Four quantitative studies reported on the food habits and one on nutritional status, and there were three qualitative studies exploring food habits and nutrition (Table 3). Studies in Europe (Spain [37] and UK [29]), U.S. [38] and Bangladesh [30] all demonstrated a significant adverse effect of the economic crisis on food intake by children, and specifically in vulnerable children. In particular the study in the UK by DEFRA [29] showed a social gradient with children from low income families eating less fruit and vegetables between 2007 and 2011. A study in Bangladesh showed an increase in the number of children who were underweight [30].

Qualitative studies found similar and consistent results both in developed and developing countries [43-47]. The increase in food prices was associated to diminishing the number and quality of meals and buying cheaper food. A gender effect was noted since the results showed that more women were affected by the crisis compared to men. Poor children from urban areas in developing countries were affected the most [47]. The usual strategy followed by families was shown to be to reducing costs by giving foods based more on carbohydrates in developed and developing countries and fast food offered an easy solution according to the UK study [46].

\subsubsection{Health Behaviours, Non-accidental Injuries, Mental Health and Health-related Quality of Life}

Twelve studies reported on health behaviours, child maltreatment, mental health and health-related quality of life (see Table 4). Higher probability of smoking for unemployed parents in families having children with asthma was found in the U.S. in 2010, but this association was not found in 2008 [39]. 
Table 3. Impact of the 2008economic crisis on food and nutrition.

\begin{tabular}{|c|c|c|}
\hline Country & Results & Study \\
\hline \multicolumn{3}{|l|}{ Quantitative Findings } \\
\hline U.S. & $\begin{array}{l}39 \% \text { of parents experienced food insecurity in } 2009 / 2010 \text { and } 13 \% \text { had very low food security. Food insecure parents } \\
\text { were more likely to be non-white, single parent, low education level, unemployed and with low income. }\end{array}$ & Bruening M. [38] \\
\hline UK & In 2012500,000 children (4\%) in the UK live in families who cannot afford to feed them properly. & Gordon D. [28] \\
\hline UK & $\begin{array}{l}\text { Households purchased } 4.2 \% \text { less food in } 2011 \text { than in } 2007 \text { while spending } 12 \% \text { more. Low income decile households } \\
\text { have bought less fruits and vegetables. }\end{array}$ & $\begin{array}{l}\text { Department for Environment } \\
\text { Food and Rural Affairs } \\
\text { (DEFRA) [29] }\end{array}$ \\
\hline Spain & $\begin{array}{l}9.8 \% \text { of families with children under the age of } 16 \text { years could not afford regular fish or meat on alternate days. } \\
\text { This figure had risen from } 1.7 \% \text { in } 2008 .\end{array}$ & Catalonian Ombudsman [37] \\
\hline Bangladesh & $\begin{array}{l}\text { The weight-for-height } \mathrm{Z} \text { score in } 2008 \text { was below the trend line for }>30-59 \text { months old children at baseline. } \\
\text { More affected groups were } 30-59 \text { months and 0-6 months old. In the rural sample wasting and underweight was } 5.5 \% \text {, } \\
\text { and this figure was } 6.7 \% \text { for the urban sample comparing with } 2006 \text {. }\end{array}$ & Sulaiman M. [30] \\
\hline \multicolumn{3}{|l|}{ Qualitative Findings } \\
\hline UK & $\begin{array}{l}\text { Food was often the first area to be cut in the family budget. Families get this buying in cheaper supermarkets, less fresh } \\
\text { fruit and vegetables and more frozen. Trading down was a common strategy lowering the quality. Another way to reduce } \\
\text { costs for families on lower incomes is buying food that would fill children up (more rice or pasta or samosas with chips). } \\
\text { Fast food offers also an easy solution. }\end{array}$ & Halls S.[46] \\
\hline $\begin{array}{l}\text { Data from } 17 \\
\text { developing countries }\end{array}$ & $\begin{array}{l}\text { Food insecurity emerged as the most severe impact of the crisis. It was more pronounced in Central African Republic and } \\
\text { Kenya, and was also common in Bangladesh and Zambia. Reducing the quality of food and the number of meals was the } \\
\text { most common behaviour-based coping response to crises. Problem of sending children to school on an empty stomach } \\
\text { was widely cited. }\end{array}$ & $\begin{array}{l}\text { Heltberg R. [43] } \\
\text { Hossain N. [44] } \\
\text { Hossain N. [45] }\end{array}$ \\
\hline Nigeria & $\begin{array}{l}\text { Families reduced consumption of food in terms of quality and quantity in Nigeria. Urban poor are more adversely } \\
\text { affected because the rural poor have their own food production. Informants identified children and women from poor } \\
\text { families as bearing the brunt of rising costs of food. }\end{array}$ & Samuels F. [47] \\
\hline
\end{tabular}


Table 4. Summary of the impact of the 2008 economic crisis on health behaviors, non-accidental injuries, mental health and health-related quality of life.

\begin{tabular}{|c|c|c|}
\hline Country & Results & Study \\
\hline \multicolumn{3}{|c|}{ Quantitative Findings } \\
\hline U.S. & $\begin{array}{l}\text { Comparing } 2007 \text { and 2010, unemployed parents showed higher probabilities to be current smokers only in } 2010 \text { OR }=1.8(1.24-2.61) \text {. Lower level of education, } \\
\text { and mental distress were other associated factors in both surveys. }\end{array}$ & Jackson T.L. [39] \\
\hline U.S. & $\begin{array}{l}\text { Increasing incidence rates of AHT * was observed from 8.9/100,000 in 2004-2007 to } 14.7 / 100,000 \text { in } 2007-2010(1.30 \text { to } 1.7) \text { for AHT * during the recession } \\
\text { period in } 3 \text { different areas from the U.S. compared to the previous period. No association was found on this outcome when admjusting for unemployment rates. }\end{array}$ & Berger R.P. [31] \\
\hline U.S. & $\begin{array}{l}\text { Increasing incidence rates on AHT *, from } 0.7 / \text { month to } 1.4 / \text { month from the non-recession to the recession period. Unemployment rates in Ohio have risen after } \\
\text { the increase in AHT. }\end{array}$ & Huang M.I. [32] \\
\hline U.S. & $\begin{array}{l}\text { A Relative risk }=1.06(p<0.05) \text { was found for high frequency of spanking in periods of worse consumarer confidence (Consumer Sentiment Index). No } \\
\text { significant changes were observed when taking into account the rest of variables in the model (unemployment rates and home foreclosure). }\end{array}$ & Brooks-Gunn J.[33] \\
\hline U.S. & No clear association was found between pre-recession and post recession period on different types of child maltreatment measures in seven U.S. States. & Millet L. [35] \\
\hline Greece & $\begin{array}{l}\text { Prevalence of psychosocial problems have risen by } 40 \% \text {, conduct disorders by } 28 \% \text {, school leaves by } 25 \% \text {, bullying by } 22 \% \text {, suicide attempts } 20 \% \text {, illegal and } \\
\text { additive substances have risen by } 19 \% \text {, and family conflicts by } 51 \% \text {. }\end{array}$ & $\begin{array}{l}\text { Anagnostopoulos } \\
\text { D.C. [42] }\end{array}$ \\
\hline U.S. & Self-rated health and reported mental health declined significantly, specially among adolescents in low-income families, at the end of the decade analyzed. & Cui W. [34] \\
\hline Spain & $\begin{array}{l}\text { A mixture impact on health was found: some health behaviors have improved as an average in the whole population (i.e., time spent on screen) while inequalities } \\
\text { in health-related quality of life appeared according to the level of education, inequalities in mental health remained, and obesity showed an important increase. }\end{array}$ & Rajmil L. [36] \\
\hline UK & $\begin{array}{l}\text { The number of children who are multiple deprivated (at least two basic needs uncovered regarding food, clothing crowded houses, and social participation) was } 2 \\
\text { million in } 1999 \text { and } 4 \text { million in 2012. Multiple-deprived housesholds in Britain have increased from } 14 \% \text { in } 1983 \text { to } 33 \% \text { in } 2012 .\end{array}$ & Gordon D. [31] \\
\hline Spain & Families suffering severe material deprivation (at least 4 items from a list of minimum 9 items) was $5.8 \%$ in 2011 and $1.6 \%$ in 2008. & Ombudsman C. [37] \\
\hline \multicolumn{3}{|c|}{ Qualitative Findings } \\
\hline $\begin{array}{l}17 \\
\text { developing } \\
\text { countries }\end{array}$ & $\begin{array}{l}\text { Stressed women took their frustrations out on children. Children were often left alone as all adult family members had to work long hours away from home. } \\
\text { Tensions within households we fairly clear and well-established, even in absence of domestic violence or abuse. Criminalisation and/or substance abuse among } \\
\text { young people was directly attributed to the pressure of the crisis. In some countries young women, and even men, were reported to be increasingly entering sex } \\
\text { work (Kenya, Zambia, Dhaka, Lusaka, Nairobi). }\end{array}$ & $\begin{array}{l}\text { Heltberg R. [43] } \\
\text { Hossain N. [44] } \\
\text { Hossain N. [45] }\end{array}$ \\
\hline Nigeria & $\begin{array}{l}\text { Mothers reported worsening mental health and changes in the amount of child care and protection. Children are adopting harmful coping mechanismes like illegal } \\
\text { livelihoods, sex work, early marriage of girls, exploitative child labour, distress sale. }\end{array}$ & Samuels F. [47] \\
\hline
\end{tabular}


An increase in the incidence rates in the U.S. for abusive head trauma (AHT) and child maltreatment was found in three studies [31-33], while no influence of the downturn period was found in one study [35]. In Greece, an increase was reported for child and adolescent patients in hospital care for various psychosocial problems from 2007 to 2011 [42].

Self-rated health declined and mentally unhealthy days increased in adolescents from the U.S., mainly among those in low-income families [34], and inequalities in health-related quality of life in children 6-14 year according to maternal level of education appeared after the start of the crisis in Catalonia, Spain [36]. Qualitative studies in developing countries highlight increased family tension and substance abuse among young people attributed to the pressure of the crisis [43-47].

\subsubsection{Chronic Conditions}

Two studies reported on children with chronic conditions from the U.S. (see Table 5). A gap in health insurance coverage in the previous year was associated to a lower asthma control in children when comparing before and during the current crisis [40].

Fifty four percent of hemophiliac patients or their caregivers reported negative impact on the management of the condition after starting the current crisis [41].

Table 5. Summary of the impact of the 2008 economic crisis on chronic conditions.

\begin{tabular}{|c|c|c|}
\hline Country & Results & Study \\
\hline U.S. & $\begin{array}{l}\text { Lack in health insurance coverage }(\mathrm{OR}=1.74 ; 1.07-2.83) \text { was the main factor associated to } \\
\text { poorly controlled asthma during the period } 2007-2009 \text {, together with intermediate-low income } \\
\text { level. Higher levels of unemployment were not associated with asthma control. }\end{array}$ & $\begin{array}{l}\text { Pearlman D.N. } \\
{[40]}\end{array}$ \\
\hline U.S. & $\begin{array}{l}54 \% \text { reported negative impact on the management of the Hemophilia in the period 2009/2010 } \\
\text { than previously: delayed or cancelled appointments, reduced or skipped doses, skipped filling } \\
\text { prescription, delayed bleeding related urgent care visit. } 22 \% \text { anticipated positive influence of } \\
\text { healthcare reform. }\end{array}$ & $\begin{array}{l}\text { Tarantino M.D. } \\
\text { [41] }\end{array}$ \\
\hline
\end{tabular}

\section{Discussion}

To our knowledge this is the first review on the effects of the 2008 economic crisis on children's health. One modelling study estimated a negative impact on infant and child mortality in sub-Saharan countries; and in Greece such impact on mortality was shown by using registered data in another study. Furthermore, quantitative and qualitative studies documented changes in food consumption and nutrition worldwide with specific impact on most vulnerable population. Other studies showed an increase in non-accidental injuries and in social inequalities in perceived health and health-related quality of life in some countries. This review also highlights the gaps in knowledge on the subject and the need for studies to generate sufficient evidence to inform effective measures to mitigate the negative impact of the economic crisis on child health.

A limitation of the review is that most of the studies were not specifically designed to analyse the impact of economic crisis on child health, and are not sufficiently robust to establish a causal relationship. As a result, the level of evidence is weak to establish clear recommendations. Overall the quality of the studies is mixed, with a low likelihood of bias in the studies based on vital statistics or in 
population representative samples, but lower quality in others. A sensitivity analysis showed that child mortality studies were not of sufficient quality to demonstrate the impact of the crisis on mortality, (e.g., the outcomes estimated on the study from sub-Saharan African countries were based on retrospective data). Qualitative studies consistently showed increased nutritional risk of children of socially disadvantaged families worldwide. An increased risk of child maltreatment has been quite consistent in studies from the U.S., and inequalities in perceived health and quality of life were found in different populations. The rest of the results should be taken with great caution given the high or average risk of bias of the included studies. However, studies were included independently of their risk of bias due to the scarcity of data and to draw attention on the lack of good quality studies. Secondly, some studies present results as averages in the population. Future studies should focus on analysing the subgroups most affected by the crisis. Thirdly, publication bias cannot be ruled out. Fourthly, it should be taken into account that a diverse group of countries-both developed and developing - was included in the review. All these countries did not experience the recession at the same time and did not define it in the same way. As a consequence, some specific results such as infant mortality should not be generalised. Finally, characteristics of the included studies did not allow us to perform a meta-analysis.

Positive effects have been described on adult mortality in previous crises in some specific countries [48]. This effect has not been reported on child mortality either in previous or in the current crisis.

It is worth noting that none of the studies were ideally designed to demonstrate causal relationships. Nevertheless, some of the studies have tried to attribute a causal relationship to the recession making necessary adjustments to strengthen these claims (e.g., adjusting for pre-recession time trends, adjusting for other time varying confounders, among other procedures).

There is sufficient accumulated evidence from previous crises showing that exposure to situations of deprivation and increasing social inequalities are damaging to children's health in the short and long term. Cohort studies of children carried out since the last century have shown the influence of social determinants on physical, cognitive and social health [49-52], and the negative cumulative effects of deprivation and stress during the first years of life on the physical and mental health status later in childhood [53,54].

High food prices reduce diversity and nutritional quality of the diet, and even quantity [55]. This is likely to impact on the most vulnerable groups in both industrialised and developing countries. The poorest populations from urban areas are the most vulnerable to food insecurity and malnutrition [56]. In developed countries, children living in families without resources or without social protection mechanisms due to austerity measures are at greater nutritional risk, including both obesity and undernutrition. The results of the present review highlight the potential nutritional risk for the most vulnerable populations.

The evidence to date demonstrates the plausibility of the association between the crisis and violence against children. In the adult population, it has been found that mental health problems, family stress, violence and suicides increased in time of crisis [57], and these often occur in families with children.

The included studies do not allow comparison of the measures taken by governments to alleviate the effects of the crisis, and this should be for a focus of future studies. Nevertheless, according to the present data, it cannot be ruled out that those countries adopting austerity measures showed high 
negative impact on child health, such as southern European countries. Future studies should confirm or discard this fact.

\section{Implications for Research and Policy}

Further research is required to establish the mechanisms by which an economic crisis affects children's health, and how to measure the exposure. It should be taken into account that economic changes usually occur rapidly, leading to deterioration in the social determinants of health, but consequent changes in health outcomes can have long latency periods and may take decades to become fully apparent.

As currently available indicators are often not sensitive to the short-term impact on health, there is a need to develop indicators that are sensitive to change $[15,58]$.

Cross country studies to assess the effects of the range of responses that have been implemented by governments during the recent economic crisis are needed and should include an assessment of effects on child health. Previous experience, such as the crisis in Nordic countries in the early 90s, suggested that no impact or a minimum impact on children's health occurred in Nordic countries given the protective effect of a highly developed welfare state and additional specific measures of child protection maintained during that crisis [59]. It is also necessary to study the epidemiology of resilience factors in order to determine the factors that mitigate the negative consequences of the crisis, including measures of social capital and family structure [1].

\section{Conclusions}

Most studies suggest that the economic crisis may pose a serious threat to children's health, and disproportionately affects the most vulnerable groups. There is an urgent need for further studies to monitor the child health effects of the global recession and to inform appropriate public policy responses.

\section{Acknowledgments}

The authors thank the librarian Marta Millaret from the Catalan Agency for Health Quality and Assessment for her help in developing the search strategy. David Taylor-Robinson was supported by a Medical Research Council Population Health Scientist Fellowship to him (G0802448).

\section{Author Contributions}

Luis Rajmil conceptualized and designed the study, carried out the literature search, analyzed the data, and drafted the initial manuscript. María-José Fernández de Sanmamed, contributed to the study design, analyzed the data, and contributed to the first draft of the manuscript. Imti Choonara, Tomas Faresjö, Anders Hjern, Anita Kozyrskyj, Patricia Lucas, Hein Raat, Louise Séguin, Nick Spencer, and David Taylor-Robinson participated in the analysis, and contributed to the first draft of the manuscript. All authors approved the final manuscript as submitted.

\section{Conflicts of Interest}

The authors declare no conflict of interest. 


\section{References}

1. Karanikolos, M.; Mladovsky, Ph.; Cylus, J.; Thomson, S.; Basu, S.; Stuckler, D.; Mackenbach, J.P.; McKee, M. Financial crisis, austerity, and health in Europe. Lancet 2013, 381, 1323-1331.

2. Rico, A.; Blakey, E. Crisis económica y desigualdades en salud (Economic crisis and health inequalities), Colección de Minitemas Online de la Escuela Nacional de Sanidad; Instituto de Salud Carlos III: Madrid, Spain, 2012. (In Spanish)

3. Suhrcke, M.; Stuckler, D. Will the recession be bad for our health? It depends. Soc. Sci. Med. 2012, 74, 647-653.

4. Early Child Development Knowledge Network (ECDKN). Early Child Development: A Powerful Equalizer; World Health Organization: Geneva, Switzerland, 2007.

5. Children and Youth in Crisis Protecting and Promoting Human Development in Times of Economic Shocks; Lundberg, M., Wuermli, A., Eds.; The World Bank: Washington, DC, USA, 2012.

6. Harper, S.; Lynch, J.; Smith, G.D. Social determinants and the decline of cardiovascular diseases: Understanding the links. Annu. Rev. Public Health 2011, 32, doi:10.1146/annurev-publhealth031210-101234.

7. Pollitt, R.A.; Rose, K.M.; Kaufman, J.S. Evaluating evidence for models of life course socioeconomic factors and cardiovascular outcomes: A systematic review. BMC Public Health 2005, 5, 7-19.

8. Cohen, S.; Janicki-Deverts, D.; Chen, E.; Matthews, K.A. Childhood socioeconomic status and adult health. Ann. N. Y. Acad. Sci. 2010, 1186, 37-55.

9. Kaplan, G.A.; Turrell, G.; Lynch, J.W.; Everson, S.A.; Helkala, E.L.; Salonen, J.T. Childhood socioeconomic position and cognitive function in adulthood. Int. J. Epidemiol. 2001, 30, 256-263.

10. Yeung, W.J.; Linver, M.R.; Brooks-Gunn, J. How money matters for young children's development: Parental investment and family processes. Child Develop. 2002, 73, 1861-1879.

11. Spencer, N. Reducing child health inequalities: What's the problem? Arch. Dis. Child. 2013, 98, 836-837.

12. Quintana, C.D.; López-Valcárcel, B.G. The economic crisis and health. Gac. Sanit. 2009, 4, 261-265.

13. Marcus, R.; Gavrilovic, M. The Impacts of the Economic Crisis on Youth: Review of Evidence; Overseas Development Institute: London, UK, 2010.

14. Starfield, B. Social Gradients and Child Health; Academic Press: San Diego, CA, USA, 2008; pp. $87-101$.

15. Institute of Health Equity UCL. The Impact of the Recession and Welfare Changes on Health Inequalities. Available online: https://www.instituteofhealthequity.org/themes/work-onrecession-and-welfare-changes (accessed on 14 August 2013).

16. Kentikelenis, A.; Karanikolos, M.; Papanicolas, I.; Basu, S.; McKee, M.; Stuckler, D. Health effects of financial crisis: Omens of a Greek tragedy. Lancet 2011, 378, 457-458.

17. González-Bueno, G.; Bellos, A.; Arias, M. La infancia en España 2012-2013, El impacto de la Crisis en los Niños; UNICEF España: Madrid, Spain, 2012. (In Spanish)

18. El Impacto de la Crisis en Las Familias y en la Infancia; Navarro, V., Clua-Losada, M., Eds.; Observatorio Social de España: Barcelona, Spain, 2012. 
19. Withham, G. Child Poverty in 2012: It Shouldn't Happen Here; Save the Children: London, UK, 2012.

20. Wise, P. Children of the recession. Arch. Pediatr. Adolesc. Med. 2009, 163, 1063-1064.

21. Child Poverty Action Group. Child Poverty Facts and Figures. Available online: http://www. cpag.org.uk/child-poverty-facts-and-figures (accessed on 16 November 2013).

22. Von Elm, E.; Altman, D.G.; Egger, M.; Pocock, S.J.; Gøtzsche, P.C.; Vandenbrouckef, J.P.; for the STROBE Initiative. The Strengthening the Reporting of Observational Studies in Epidemiology (STROBE) statement: Guidelines for reporting observational studies. Bull. WHO 2007, 85, 867-872.

23. Stige, B.; Malterud, K.; Midtgarden, T. Toward an agenda for evaluation of qualitative research. Qual. Health Res. 2009, 19, 1504-1516.

24. Ariizumi, H.; Schirle, T. Are recessions really good for your health? Evidence from Canada. Soc. Sci. Med. 2012, 74, 1224-1231.

25. Friedman, J.; Schady, N. How many infants likely died in Africa as a result of the 2008-2009 global financial crisis? Health Economics 2013, 22, 611-622.

26. Simó, J. Los Niños, Primeras Víctimas Mortales de la Crisis en Grecia. Available online: http://saluddineroy.blogspot.com.es/2013/02/los-ninos-primeras-victimas-mortales-de.html?spref=tw (accessed on 21 June 2013).

27. Vlachadis, N.; Kornarou, E. Increase in still births in Greece is linked to the economic crisis. BMJ 2013, 346, doi:101136/bmj.f1061.

28. Gordon, D.; Mack, J.; Lansley, S. Mack, J.; Lansley, S.; Main, G.; Nandy, S.; Patsios, D.; Pomati, M. The Impoverishment of the UK; Poverty and Social Exclusion (PSE): Bristol, UK, 2013.

29. Exploratory Analysis and Trends Informing Policy. In Family, Food 2011; Department for Environment, Food \& Rural Affairs (DEFRA): London, UK, 2012; Chapter 5.

30. Sulaiman, M.; Parveen, M.; Das, N.C. Impact of the Food Price Hike on Nutritional Status of Women and Children; Research and Evaluation Division: Dhaka, Bangladesh, 2009.

31. Berger, R.P.; Fromkin, J.B.; Stutz, H.; Makoroff, K.; Scribano, P.H.; Feldman, K.; Tu, L.C.; Fabio, A. Abusive head trauma during a time of increased unemployment: A multicenter analysis. Pediatrics 2011, 128, 637-643.

32. Huang, M.I.; O’Riordan, M.A.; Fitzenrider, E.; McDavid, L.; Cohen, A.R.; Robinson, S. Increased incidence of nonaccidental head trauma in infants associated with the economic recession. J. Neurosurg. Pediatr. 2011, 8, 171-176.

33. Brooks-Gunn, J.; Schneider, W.; Walfogel, J. The great recession and the risk for child maltreatment. Child Abuse Neglect 2013, doi:10.1016/j.chiabu.2013.08.004.

34. Cui, W.; Zack, M.M. Trends in health-related quality of life among adolescents in the United States, 2001-2010. Prev. Chronic Dis. 2013, doi:10.5888/pcd10.120334.

35. Millet, L.; Lanier, P.; Drake, B. Are socioeconomic trends associated with maltreatment? Preliminary results from the recent recession using state level data. Child Youth Serv. Rev. 2011, 33, 1280-1287.

36. Rajmil, L.; Medina-Bustos, A.; de Sanmamed, M.J.F.; Mompart, A. Impact of the economic crisis on children's health in Catalonia: A before-after approach BMJ Open 2013, 3, doi:10.1136/bmjopen-2013-003286. 
37. Síndic de Greuges de Catalunya (Catalonian Ombudsman). Informe Sobre la Malnutrició Infantil a Catalunya (in Spanish); Síndic de Greuges: Barcelona, Spain, 2013.

38. Bruening, M.; MacLehose, R.; Loth, K.; Story, M.; Neumark-Sztainer, D. Feeding a family in a recession: Food insecurity among Minnesota parents. Amer. J. Public Health 2012, 102, 520-526.

39. Jackson, T.L.; Gjelsvik, A.; Garro, A.; Pearlman, D.N. Correlates of smoking during an economic recession among parents of children with asthma. J. Asthma 2013, 50, 457-462.

40. Pearlman, D.N.; Jackson, T.L.; Gjelsvik, A.; Viner-Brown, S.; Garro, A. The impact of the 2007-2009 U.S. recession on the health of children with asthma: Evidence from the national Child Asthma Call-back Survey. R. I. Med. J. 2012, 95, 394-396.

41. Tarantino, M.D.; Ye, X.; Bergstrom, F.; Skorija, K.; Luo, M.P. The impact of economic downturn and health care reform on treatment decisions for Hemophilia A: Patient, caregiver and health care provider perspectives. Haemophilia 2013, 19, 51-58.

42. Anagnostopoulos, D.C.; Soumaki, E. The state of child and adolescent psychiatry in Greece during the international financial crisis: A brief report. Eur. Chid. Adolesc. Psychiatr. 2013, 22, 131-134.

43. Living through Crises: How the Food, Fuel, and Financial Shocks Affect the Poor; Heltberg, R., Hossain, N., Reva, A., Eds.; World Bank: Washington, DC, USA, 2012.

44. Hossain, N.; Eyben, R. Accounts of Crisis: Poor People's Experiences of the Food, Fuel and Financial Crises in Five Countries; Institute of Development Studies: London, UK, 2009.

45. Hossain, N.; McGregor. J.A. A "Lost Generation"? Impacts of complex compound crises on children and young people. Dev. Policy Rev. 2011, 29, 565-584.

46. Hall, S.; Perry, C. Family Matters: Understanding Families in an Age of Austerity; Social Research Institute: London, UK, 2013.

47. Samuels, F.; Gavrilovic, M.; Harper, C.; Niño-Zarazua, M. Food, Finance and Fuel: The Impacts of the Triple $F$ Crisis in Nigeria, with a Particular Focus on Women and Children; Overseas Development Institute: London, UK, 2011.

48. Franco, M.; Bilal. U.; Orduñez, P.; Benet, M.; Morejón, A.; Caballero, B.; Kennelly, J.F.; Cooper, R.S. Population-wide weight loss and regain in relation to diabetes burden and cardiovascular mortality in Cuba 1980-2010: Repeated cross sectional surveys and ecological comparison of secular trends. BMJ 2013, doi:10.1136/bmj.f1515.

49. Feinstein, L. Inequality in the early cognitive development of British children in the 1970 cohort. Economica 2003, 70, 73-97.

50. Braveman, P.A.; Egerter, S.A.; Mockenhaupt, R.E. Broadening the focus: The need to address the social determinants of health. Amer. J. Prev. Med. 2011, 40, S4-S18.

51. Harper, S.; Lynch, J.; Smith, G.D. Social determinants and the decline of cardiovascular diseases: Understanding the links. Annu. Rev. Public Health 2011, 32, 39-69.

52. Braveman, P.; Egerter, S.; Williams, D.R. The social determinants of health: Coming of age. Annu. Rev. Public Health 2011, 32, 1-18.

53. Séguin, L.; Nikiéma, B.; Gauvin, L. Childhood Poverty, Cumulative Adversities and, Chronic Health Conditions at 10 Years Old in the Quebec Birth Cohort; APHA: San Francisco, CA, USA, 2012. 
54. Spencer, N.; Tu, M.T.; Séguin, L. Low income/socio-economic status in early childhood and physical health in later childhood/adolescence: A systematic review. Matern. Child Health J. 2012, doi:10.1007/s10995-012-1010-2.

55. De Pee, S.; Brinkman, H.J.; Webb, P.; Godfrey, S.; Darnton-Hill, I.; Alderman, H.; Semba, R.D.; Piwoz, E.; Bloem, M.W. How to ensure nutrition security in the global economic crisis to protect and enhance development of young children and our common future. J. Nutr. 2010, 140, S138-S142.

56. Ruel, M.T.; Garret, J.; Hawkwa, C.; Cohen, M.J. The food, fuel, and financial crisis affect the urban and rural poor disproportionately: A review of evidence. J. Nutr. 2010, 140, S170-S176.

57. Lopez-Bernal, J.A.; Gasparrini, A.; Artundo, C.M.; McKee, M. The effect of the late 2000s financial crisis on suïcides in Spain: An interreupted time-series analysis. Eur. J. Public Health 2013, 23, 732-736.

58. Garcia, M. Mortality rates or sociomedical indicators? The work of the League of Nations on standardizing the effects of the great depression on health. Health Policy Plann. 2012, doi:10.1093/heapol/czs111.

59. Bremberg, S. Does an increase of low income families affect child health inequalities? A Swedish case study. J. Epidemiol. Community Health 2003, 57, 584-588.

(C) 2014 by the authors; licensee MDPI, Basel, Switzerland. This article is an open access article distributed under the terms and conditions of the Creative Commons Attribution license (http://creativecommons.org/licenses/by/3.0/). 